\title{
Comparing Land Reform and Land Markets in Colombia Impacts on Equity and Efficiency
}

\author{
Klaus Deininger \\ Raffaella Castagnini \\ María A. González \\ World Bank, Washington, D.C., USA \\ University of Connecticut, Storrs CT, USA
}

World Bank Policy Research Working Paper 3258, April 2004

The Policy Research Working Paper Series disseminates the findings of work in progress to encourage the exchange of ideas about development issues. An objective of the series is to get the findings out quickly, even if the presentations are less than fully polished. The papers carry the names of the authors and should be cited accordingly. The findings, interpretations, and conclusions expressed in this paper are entirely those of the authors. They do not necessarily represent the view of the World Bank, its Executive Directors, or the countries they represent. Policy Research Working Papers are available online at http://econ.worldbank.org.

We thank Elsa Albarracin, Ruth Suarez, and Katja Vinha for making data available and Diana Grusczynski, Ana Maria Ibanez, Felipe Jaramillo, and Isabel Lavadenz for comments. 


\title{
Land Reform and Land Markets in Colombia:
}

\author{
Impacts on Equity and Efficiency
}

\begin{abstract}
Based on a large survey to compare the effectiveness of land markets and land reform in Colombia, we find that rental and sales markets were more effective in transferring land to poor but productive producers than was administrative land reform. The fact that land transactions were all of a short-term nature and that little land was transferred from very large to small land owners or the landless suggests that there may be scope for policies both to improve the functioning of land markets and to facilitate greater land access by the most disadvantaged. Analysis of the factors associated with success in a sample of land transfers from large to small producers helps to identify key elements for policies in both respects.
\end{abstract}

Keywords: Land markets, Land reform, Colombia, Agricultural Productivity

\section{Introduction}

In many developing countries, a highly unequal distribution of land makes it more difficult to sustainably reduce poverty. One reason for this is that lack of land access in the context of an unequal distribution of land can create obstacles that may prevent the poor from accessing credit markets to make discrete investments, e.g. in schooling or to take advantage of other economic opportunities (Aghion et al. 1999). The literature has long emphasized that in a world where credit markets are imperfect, a highly unequal distribution of assets and economic opportunities will reduce both household ability to invest and social cohesion, and thus, ultimately, economic growth (Deininger and Olinto 2000). The dependence of landless households on the continued goodwill of landlords to provide them with land for their sustenance rather than ownership reduces their shadow wage, thus reducing the cost of hired labor, but also reducing the incentives for the landless to acquire human capital (Binswanger et al. 1995, Conning 2002). This will also reduce the scope for establishing independent institutions, with potentially far-reaching and adverse consequences for economic and social development (Nugent and Robinson 2002). Finally, an unequal distribution of land ownership, together with lack of efficient land markets that could help bring land to its most appropriate use, will often lead to significant inefficiency in utilization of land and underinvestment.

This is at the root of the seeming paradox that in many countries with highly unequal land distribution, lack of land access and environmentally unsustainable cultivation of marginal areas by the poor often goes hand in hand with underutilization of large tracts of productive land. Aspects of this problem have been illustrated for Colombia (Heath and Binswanger 1996), Brazil (World Bank 2003b), Zimbabwe and Southern Africa (Moyo et al. 2000), and the Philippines (Putzel 1992). There is consensus that dealing 
with the legacy of unequal access to land and economic opportunities may not only be highly desirable from a social equity perspective, but can also be a boost to economic growth and greater efficiency (Deininger 2003).

As much of the inequality in the land ownership distribution has its origin in non-market interventions, policy-makers have often assumed that markets will not be able to help correct, and may even reinforce or worsen, pre-existing inequalities in land access or ownership. Instead, it was believed that government intervention would be needed to deal with the legacy of a highly skewed land ownership distribution.

Three insights suggest that there may be a need to rethink this position. First, even though there are some notable exceptions, such as in the case of Japan, Korea and Taiwan, most government-sponsored land redistributions have failed to meet the associated expectations. This suggests that, at least in some situations, the implications of "government failure" may be as undesirable as those arising from the market failures such intervention was supposed to overcome.

Second, it is now realized that households access land through a variety of mechanisms. Because rental and sales markets will be affected very differently by the market imperfections common in many rural areas, a more differentiated judgment will be needed. Also, that the complementarities between different types of land access may be much larger than initially presumed. In fact, recent evidence from a number of countries suggests that rental markets transfer land to the poor and more productive (Sadoulet et al. 2001, Deininger and Mpuga 2002, Deininger and Jin 2002, Rozelle and Swinnen 2003). While this may be less the case with land sales markets that tend to be more affected by imperfections in financial markets than those for rental, markets are part of the reality of rural areas. Better understanding of the advantages and disadvantages of markets in any given situation, with the aim of complementing them where needed, is likely to be more promising than trying to pursue a strategy of wholesale substitution (Tejo 2003).

Third, there is evidence that, even in situations where land was successfully redistributed, constraints on the functioning of markets may limit beneficiaries' ability to realize the full gains from such reforms by transferring their use (Rawal 2001) or ownership rights (Kawagoe 1999). In fact, elimination of restrictions on the ability of land reform beneficiaries to engage in land transactions does have significant economic benefits.

While all of these arguments suggest that researchers recognize the importance of different avenues to access land (de Janvry et al. 2001), empirical evidence that compares different mechanisms to access land is still scant. More detailed empirical analysis is necessary if the awareness on multiple access options to 
land is to be transformed into specific policy advice. In this paper, we use the example of Colombia to explore this issue empirically.

The paper is structured as follows. Section two provides the background and conceptual framework by describing salient characteristics of land relations in Colombia, drawing on the literature to develop testable hypotheses concerning the performance of land sales, rentals, and land reform, and describing the data and estimation strategy to be used. Section three provides descriptive statistics and reports the results from econometric analysis to test these hypotheses. Section four links the results to the broader policy context by assessing aggregate changes in land concentration, reviewing attributes associated with success in a sample of land transfers from large to small or landless producers, and discussing implications for policies to increase land access. Section five concludes with a number of policy recommendations.

\section{Background and conceptual framework}

To provide the necessary factual and conceptual background, this section briefly discusses the evolution of land policy in Colombia as well as the literature regarding the advantages and disadvantages of different types of land markets. We use this to introduce the data to be used and the empirical strategy to be employed.

\subsection{Land markets and land reform in Colombia}

Colombia, like other Latin American countries, is characterized by a highly dualistic distribution of land ownership, the roots of which can be traced back to colonial land grants (encomiendas). The high level of inequality has been maintained by policy-related factors including (i) tax incentives for agriculture that caused rich individuals to acquire land to offset taxes on nonagricultural enterprises, (ii) credit and interest rate subsidies plus disproportionate protection of the livestock sub-sector that provided incentives for agricultural cultivation with very low labor intensity, and (iii) the use of land to launder money that had been acquired by drug lords. Most of these interventions worked disproportionately in favor of large farmers (Heath and Binswanger 1996). By raising land prices significantly above the net present value of profits from agricultural production, they made it nearly impossible for productive small farmers to acquire land through the land sales market (Carter and Mesbah 1993). Land rental was impeded by tenure insecurity and ill-conceived laws that outlawed share tenancy in an attempt to improve the welfare of tenants but instead were conducive to eviction of tenants and increased cattle ranching (Jaramillo 1998). All of this restricted the options for the poor to gain access to land and often left state-sponsored land reform as virtually the only mechanism to facilitate land transfers to the poor. 
Aggregate data illustrate the tendency toward increasing land concentration during the early 1990s. As table 1 illustrates, despite growing population pressure and the associated fragmentation, this period was characterized by land transfers from small and medium toward large farms. Adjusting for land quality, the number of "small" farm units (comprising less than two Unidades Agricolas Familiares [UAFs] ${ }^{1}$ ) increased slightly, from $89.9 \%$ to $91.1 \%$ of all farms, and the share of area cultivated by these shows a slight decrease, from $23.1 \%$ in 1984 to $21.4 \%$ in 1997 . A more significant reduction in area, from $30.5 \%$ to $24.8 \%$ with almost constant share in the farm units, is observed for medium-sized farms. Large farms increased their share of area from $46.3 \%$ to $53.8 \%$. The lower panel illustrates that this conclusion is even more pronounced if physical area is taken as the basis for the assessment. This situation has increased the propensity of violence in rural areas creating insecurity and reducing the incentive to invest (Machado 1999, Mondragon 1999).

The data also support the close link between land concentration and inefficient land use whereby a significant amount of arable land is left unused while marginal areas that are often ill-suited for such exploitation are dedicated to extensive livestock ranching (Grusczynski and Jaramillo 2002). The extent of mis-allocation of resources this implies is illustrated in table 2 which compares actual with potential land use in Colombia in 1999. Out of a total area of 114.2 million hectares, about $12 \%$ is suitable for agriculture. In 1999, only $30 \%$ of this land was actually devoted to crop production, pointing to severe underutilization. At the same time, there was over-exploitation of land for pasture. Although only $17 \%$ of the total land is suitable; more than double this amount is actually used for pasture.

The negative economic and social consequences of such unequal land access have been known for a long time: in fact a 1950 World Bank mission identified unequal land distribution as a key impediment to economic and social development in the country (Currie 1950). ${ }^{2}$ While various policies have been adopted to deal with this, their success was limited by a combination of an inappropriate policy environment, limited financial resources, cumbersome processes loaded with bureaucratic obstacles, and the impact of drug money and violence on the rural economy. The national land reform institute (INCORA), which was established in 1961, found it easier and politically more expedient to colonize the frontier than to redistribute land in the country's interior, and the impact of the government's land reform effort is judged to have been very limited. More than a quarter century of land reform has done little to bring about substantive change in either land ownership or operational distribution of land (Machado 1999).

1 The UAF is the area of land which, for given agroecological conditions, can generate income for a family. Because the UAF is defined at the level of municipalities and natural regions within these, it provides a better way of accounting for the potentially vast differences in land quality that are difficult to integrate into the analysis if only physical farm size is considered. 
Starting in the 1990s, and following earlier steps to eliminate a number of restrictions on the functioning of land rental markets, Colombia embarked on a series of macro-economic and sectoral policy reforms that significantly opened up the rural economy (Jaramillo 2001). The elimination of policy interventions in the early 1990s was combined with a new land reform law, passed in 1994, that aimed to establish a more integrated process with a greater role for beneficiary initiative (Deininger 1999). Spending on land reform increased significantly; as illustrated in table 3, the amount of resources spent by INCORA alone increased from about 8\% of the Ministry's central budget in the 1980s to 13\% in 1997 (FAO 2000). Together with loans by the then Caja Agraria that were largely devoted to land reform beneficiaries, many of whom were unable to pay them back, resources spent directly or indirectly on land reform accounted for $35 \%$ of the central or about $20 \%$ of the total agricultural budget.

The goal of these policy measures was the reduction of incentives for speculative land acquisition and the elimination of the advantages that were traditionally enjoyed by large land owners and cattle ranchers. Such reforms would make it easier for market forces to work, thereby opening up alternative forms of land access for poor but efficient producers. Given the large magnitude of the resources involved, assessment of the extent to which, after the reforms, markets helped to bring about a redistribution of land, and how their results compare with those obtained by the government's program will be of great interest for policy.

\subsection{Comparing different modalities of land transfer}

The literature suggests that, because they are generally associated with low transaction costs and because possible working capital constraints on the part of the tenant can generally be overcome through sharing arrangements, rental markets provide a flexible way of transferring use rights among producers, thereby improving productivity of land use. The ability to transfer ownership in land sales markets provides the advantage of enabling the owner to use land as collateral in credit markets, in addition to possible greater investment incentives, but comes at the cost that the outcome from land sales is more likely to be affected by imperfections in the functioning of financial markets.

To compare the performance of land rental and sales markets with land reform, let household $i$ be endowed with fixed amounts of labor $\left(\bar{L}_{i}\right)$ and land $\left(\bar{A}_{i}\right)$, and a given level of agricultural ability $\left(\alpha_{i}\right)$. Households can allocate their labor endowment between farming their own land and off-farm employment at an exogenous wage $\left(w_{i}\right)$. Renting or selling of land incurs transaction costs $(T)$

\footnotetext{
2 “...the cattle fatten on the plains while the people often have to struggle for a bare existence in the hills. ... As a result, they exploit the land very severely, adding to erosion and other problems, and even so are not able to make a decent living. This pattern of land use is one of the most important causes of low labor productivity in agriculture and of resulting widespread poverty in rural areas" (Currie 1950:63).
} 
proportional to the amount of land transferred, and we assume that working capital is not binding. With this, household $i$ will choose $l^{a}, l^{o^{*}}$ as well as $A^{*}$ by solving the maximization problem:

$$
{ }_{l^{a}, A}^{\operatorname{Max}} \mathrm{pa}_{i} f\left(l_{i}^{a}, A_{i}\right)+w l_{i}^{o}-I^{\text {in }}\left(A_{i}-\bar{A}_{i}\right)(r+T)+I^{\text {out }}\left(\bar{A}-A_{i}\right)(r-T)
$$

where $p$ is the price of agricultural output, $l^{o}$ is the amount of time allocated to off-farm labor $\left(=\bar{L}_{i}-l_{i}^{a}\right)$, $I^{\text {in }}$ is an indicator for rent-in (=1 for rent-in, and 0 otherwise), similarly $I^{\text {out }}$ is an indicator for rent-out ( $=1$ for rent-out, and 0 otherwise), and all other variables in (a) are as defined above. The optimal choices of $l_{i}^{a^{*}}, l_{i}^{o^{*}}$ and $A_{i}{ }^{*}$ will solve the first-order conditions (FOC) of problem (P) (see Deininger and Jin (2002) for detailed derivation of the FOC). Under these assumption, solving the maximization problem by household $i$ and developing first-order conditions allows us to derive propositions about the functioning of land rental markets that can then be tested empirically.

Rental markets: It can be shown that the amount of land rented in will be strictly increasing in ability, $\alpha$, and be strictly decreasing in land endowment, $\bar{A}$ (Deininger et al. 2003). Rental markets will thus transfer land from less productive to "poor but efficient" producers, as a direct consequence of the negative relationship between farm size and productivity as often asserted in the literature (Carter 1984, Binswanger et al. 1995, Benjamin 1995). While the welfare impact of such a transfer would depend on how the gains from the contract will be distributed among the parties, we expect that rental will lead toward an equalization of the distribution of operational land holdings irrespective of the land ownership structure. Higher transaction costs will drive a wedge between what is received by those renting out and what is being paid by those renting out, thereby decreasing the number of transactions. Presence of offfarm opportunities has the opposite effect; producers with low ability will take on off-farm jobs and rent out to those with higher levels of ability, thereby increasing aggregate production. This will be associated with a decrease in the equilibrium rental rate and, unless there is high risk of job loss in the off-farm sector, will make everybody better off.

Sales markets: Expanding the above model to accommodate land sales in the presence of stochastic income is analytically complex and the literature has generally resorted to simulation to obtain solutions (Zeldes 1989, Deaton 1991, Rosenzweig and Wolpin 1993). One key result from such simulation is that the speed at which markets will be able to shift land to poor but efficient producers will depend on the level of credit market imperfections and the frequency and magnitude of exogenous shocks. The parameter values encountered in most empirical situations imply that the scale and speed of redistribution through markets will be well below the socially desirable level (Carter and Zimmerman 2000). Given the higher transaction costs, the amount of transactions will always be much less than in rental markets. 
Moreover, in an environment characterized by capital market imperfections, the scope for acquiring land through the sales markets will depend more on asset endowments than on ability.

Land reform: Imperfections in capital markets make it difficult for the poor to acquire land despite their inherent productivity advantage and such market imperfections may lead to the permeation over time of inefficient structures of asset ownership (Zimmerman and Carter 2003). Direct transfers of land to landless and small producers or targeted support that would enable them to acquire land through other means would, under certain conditions, help to break out of such an inefficient equilibrium toward one characterized by higher levels of growth and social welfare (Bardhan 2000). While the need to remedy market imperfections can provide a justification for such intervention, selection of the most able beneficiaries is often not easy, given that ability is not easily observed by outsiders (Deininger and Jin 2002). Replacing impersonal market forces with discretionary bureaucratic action can also introduce distortions of its own, especially if it is difficult to write incentive compatible contracts and if supervision costs are high. In such circumstances, these may compromise the potential impact of a land reform policy and imply that other mechanisms to improve land access by the poor would be appropriate.

\subsection{Data sources and estimation strategy}

To assess the performance of land markets in Colombia, we use panel data on about 1,270 farm units from a two-round survey undertaken by the Colombian government in collaboration with IICA and the World Bank. ${ }^{3}$ Data were collected from 55 clusters in Colombia's 11 main agro-ecological regions in 1997 and 1999. To obtain maximum variation of farm sizes, large operations, drawn from lists of sugar, banana, coffee, and oil palm enterprises in the selected clusters, were oversampled. A multi-purpose survey instrument was used to obtain detailed information on agricultural production, land market participation, and tenure status. In the roughly 1,000 cases of household-based enterprises, the household associated with the production unit was canvassed using a standard household questionnaire. To account for differences between arable, permanent, pasture, and fallow land, we convert land into equivalent units by multiplying the different classes. ${ }^{4}$

To empirically estimate the relationships between participation in land rental and sales markets or land reform, ability, land endowments, household and community characteristics as outlined above, we need an estimate of the ability $\alpha_{i j}$ of farm $i$ in village $j$. To do so, we use a Cobb-Douglas production function:

$$
Q_{i j t}=\exp \left(\alpha_{i}+\alpha_{j}\right) A_{i j t}^{\theta_{1}} L_{i j t}^{\theta_{2}} K_{i j t}^{\theta_{3}}
$$

\footnotetext{
${ }^{3}$ The surveys are being referred to as the primera and segunda encuesta de calidad de vida y eficiencia de los productores agricolas (PECVE and SECVE). The basic unit of observation was the farm or UPA (Unidad de Producion Agraria) although a module on household characteristics was administered to all farms where such a household could be identified.

${ }^{4}$ The factors used are 2 for perennials, 0.5 for pasture, 0.3 for forest, and 0.1 for other non-productive land.
} 
where $Q_{i j t}$ is agricultural output produced by household i in village $j$ in year $t ; A_{i j t}, L_{i j t}$ and $K_{i j t}$ are land, labor and capital inputs used, $\theta_{1}, \theta_{2}$, and $\theta_{3}$ are technical coefficients to be estimated, and $\exp \left(\alpha_{i}+\alpha_{j}\right)$, is the efficiency parameter of interest. Taking logs of both sides, adding a time trend $T$ and an iid error term, we obtain an estimable equation for production by household as follows. ${ }^{5}$

$$
\log \left(Q_{j i t}\right)=\alpha_{i j}+\lambda_{1} \log \left(A_{j i t}\right)+\lambda_{2} \log \left(L_{j i t}\right)+\lambda_{3} \log \left(K_{j i t}\right)+\lambda_{4} T+\varepsilon_{j i t}
$$

where $\alpha_{i j}=\alpha_{j}+\alpha_{i}$ is the composite efficiency parameter, composed of a household-level idiosyncratic element $\left(\alpha_{i}\right)$ and a village-level effect $\left(\alpha_{j}\right)$ which reflects access to infrastructure and markets, soil quality, climate, etc. Agricultural land markets are location-specific with little scope for trading across municipios or departamentos, implying that the parameter of interest for land market participation is $\alpha_{i}$, i.e. each producer's ability relative to the village mean. Availability of multiple observations per household in the panel allows us to obtain this parameter in a two-step procedure where we first run a panel regression to recover $\alpha_{i j}$ and, after subsequent application of the same procedure at the regional level that helps to recover $\alpha_{j}$, we obtain the variable of interest, $\alpha_{i}$, by simple subtraction.

To capture determinants of land rental market participation, we estimate an equation of the form

$$
R_{i}=\beta_{0}+\beta_{1} \alpha+\beta_{2} \boldsymbol{X}_{i}+\beta_{3} \boldsymbol{Z}_{i}+\epsilon_{i t}
$$

where $R_{i}$ is a dummy that equals one if the household is renting in or out and zero otherwise and the parameter $\alpha_{i}$ is the household's level of agricultural ability constructed as explained above. The vector $\boldsymbol{X} i$ contains household characteristics, in particular household size and composition, and the head's age and education, households' endowment with land and other agricultural and non-agricultural assets in value terms, and a dummy indicating whether or not a household member participated in non-farm employment. Finally, $\boldsymbol{Z}_{i}$ denotes community characteristics, including the share of producers, excluding the producer under concern ${ }^{6}$, participating in credit or rental markets in the municipality, which are taken to reflect municipio-specific levels of transaction costs in land and credit markets.

From the discussion of rental markets, we expect that $\beta_{l}>0$, in the rent-in and $\beta_{l}<0$ in the rent-out equation, i.e. producers with higher ability will rent in while those with low ability will rent out. The fact that we expect land rental markets transfer land from large owners to small producers who will be able to make more productive use of this asset implies that the element of $\beta_{2}$ corresponding to the amount of land owned be positive in the rent-out and negative in the rent-in equation. If markets for other factors,

\footnotetext{
${ }^{5}$ To estimate the Cobb Douglas production function we take logarithm of both sides of the equation, avoiding the problem of zeros, by including a dummy variable for positive values of each input, something that has been demonstrated to yield unbiased estimates (Battese 1997).

${ }^{6}$ Let the number of producers in any given cluster be given by $N$, the number of those participating in rental (or credit) markets by $M$ (or $C$ ), and let $m$ or $c$ be a dummy variable that equals 1 if the producer under concern participates in rental (or credit) markets and 0 otherwise. Then the variable included in the regression is defined as $(M-m) /(N-1)$ or correspondingly $(C-c) /(N-1)$.
} 
especially capital, are functioning well, households' composition and their ownership of other assets should not have a significant impact on decisions regarding production and participation in rental or sales markets. Finding a significant coefficient on capital would therefore point toward imperfections in markets for working capital that make it impossible to use, for example, a future harvest as collateral to finance production inputs. Similarly, if labor markets function well, household size and composition should not affect rental market participation. Finding significance of the respective element of $\beta_{2}$ (positive for renting in or negative for renting out) would therefore point to labor market imperfections whereby it is easier for households to use family labor in agricultural production than to obtain wage employment. In line with proposition 3 we expect the element of $\beta_{2}$ corresponding to non-farm employment to be negative at the household level.

Finally, we use the level of rental activity in a given village as explained above to proxy for transaction costs in these markets. The justification for doing so is that for any producer the marginal costs associated with participation in land markets, e.g. inquiring about prices and supply, negotiating the terms of transfer, and enforcing contracts will decrease with the village-wide level of market activity. A similarly constructed variable on the share of producers having access to formal credit is used as a proxy for credit supply and is introduced to assess whether availability of infrastructure at the local level has an impact on land market outcomes. Other unobserved community-level characteristics such as access to infrastructure and markets, are represented by regional dummies.

For participation in the sales market, we estimate a similar equation

$$
S_{i}=\beta_{0}+\beta_{1} \alpha+\beta_{2} \boldsymbol{X}_{i}+\beta_{3} \boldsymbol{Z}_{i}+\epsilon_{i t}
$$

with $S_{i}$ denoting participation in land sales or purchase markets. Definitions of most right hand side variables are as above with the exception that $\boldsymbol{X} i$ now includes variables for initial endowments wherever available and the transaction cost element in $\boldsymbol{Z}_{i}$ is approximated by the level of sales market activity excluding the producer under concern. The key difference between sales and rental markets is that imperfections in credit, other policy distortions, and non-economic factors that affect the perceived value of land will have a more profound impact on the outcomes observed in the latter. If the ability to overcome imperfections in markets for credit and insurance is more important than the ability to make productive use of the land, $\beta_{l}$ in (3b) may no longer be positive for purchases. Similarly, if land is held for speculation and other non-productive purposes even though doing so is not economically rational, the coefficient on ability will no longer be negative in the sales equation and education which will increase the ability to make productive use of land may no longer be as relevant. The same rationale, in addition to the ability to overcome capital market imperfections, would imply that land may no longer be acquired by 
those with lower initial land ownership or sold by those with large endowments, and that initial access to assets (or off-farm income streams) may have an overriding impact on purchase or sales decisions.

Finally, to assess how the government's land reform program compares to the performance of decentralized markets, we specify equation (3c) where the dependent variable, $B_{i}$ denotes a dummy that equals 1 if the biggest part of a household's land was received through INCORA and 0 otherwise.

$$
B_{i}=\beta_{0}+\beta_{1} \alpha+\beta_{2} \boldsymbol{X}_{i}+\beta_{3} \boldsymbol{Z}_{i}+\epsilon_{i t}
$$

Rather than helping to draw inferences on the performance of decentralized markets as before, the coefficients in this equation will provide insights on the extent to which government intervention has been targeted toward poor but relatively productive producers, i.e. those with high agricultural ability $\left(\beta_{1}\right)$, low initial endowments of land and non-land assets, and possibly low levels of education. Even though a rigorous assessment of the productivity impact of land reform would require a comparison of the productivity of the same plot of land before and after being subjected to land reform, the ability to target reform toward more productive producers would obviously make it more likely to have a positive productivity impact. The ability to provide land access to poor producers who presumably would not be able to access land through other means provides a key justification for such an intervention and finding that it has not been well targeted would provide a strong argument to review either the justification for or the specific mechanisms used in such an intervention.

\section{Empirical evidence}

Implementing the above framework, we find that land rental indeed provides considerable opportunities to the productive poor for accessing land. This impact is less pronounced for land sales if the extent of area transferred is considered, as predicted. Most surprisingly, land reform failed to improve equity and efficiency, leading to the question of whether markets alone might be sufficient to address Colombia's land access issues.

\subsection{Descriptive statistics}

Descriptive statistics, separately for all enterprises and the household sample, are given in table 4 for subgroups defined by the nature of their land market and land reform program participation. The top row demonstrates that about $14 \%$ of enterprises in the sample rented in, $4 \%$ rented out, and $11 \%$ (or slightly above 2\% per year) had, over the 5-year period from 1994 to 1999, engaged in land purchases, and about $6 \%$ had sold land. The fact that $10 \%$ of sample households had benefited from the land reform program illustrates the importance of government-sponsored land market intervention compared to the operation of 
free markets. While it is not surprising to find significant differences in median endowments of capital in the form of livestock and machinery which are about $75 \%$ higher for the whole sample as compared to households only, the fact that levels of output per hectare do not follow this trend is of interest. Heads of household are, with an average of 53 years, quite old, the mean level of education is almost 7 years of schooling, and $18 \%$ of heads were female.

Comparing household characteristics across the different groups suggests that land markets perform an important function of inter-generational transfer as evidenced by the fact that those who acquired land in the market, either through rental or sale, are significantly younger and, in the case of rental, also have larger households than the rest. Rental markets appear to contribute to equalization of the operational distribution of land; in fact for both groups the median tenant in the sample own no or hardly any land. Partial productivity, as approximated by both the gross value of output per hectare and this figure net of variable inputs excluding unpaid family labor, is significantly higher for those renting than for the rest of the sample. This relationship is less clear for land buyers where none of these differences is statistically significant. Concerning land reform beneficiaries, it is of interest to note that, even though total output is in line with that achieved by others, median land endowments for reform beneficiaries are quite large, suggesting that this group may not make the most effective use of the resources at their disposal, a hypothesis that is supported by a relatively low level of output per hectare.

\subsection{Land market participation}

Results of estimating equations (3a) and (3b), with a zero/one indicator for participation in land rental and sales markets, and a dummy for having benefited from land reform, are illustrated in table $5^{7}$. In line with the conceptual discussion, we are interested in the impact of agricultural ability as well as initial land holding to ascertain the productivity- and equity-impact of land sales and rental markets, respectively, compared to redistributive land reform ${ }^{8}$. Results for participation (probit) suggest that land rental but not sales markets increase the access to land by producers who are more productive and who own less land. Government land reform has failed on both counts; the highly significant and positive coefficient on beneficiaries' pre-participation land endowment implies that reform efforts were not well targeted to the poor whereas the negative coefficient on their ability suggests that, at least compared to the average land holding, government-sponsored land redistribution did not lead to productivity gains. At the same time, tobit models for the area exchanged in land rental and sales markets (table 6) indicate that productive efficiency does not facilitate access to greater areas of land and that, even though land rental markets have

\footnotetext{
${ }^{7}$ As the survey did not ask for the amount of area that was transferred under land reform, we can only estimate a probit model for land reform participation.

${ }^{8}$ We discuss first the rental and then the sales and land reform equations. Given that tobit estimates led to very similar results, we limit our discussion to results from the probit regressions.
} 
a significant element of redistribution to producers with low land endowments, purchase markets do not facilitate greater access to land by those with small endowments. This implies that detailed consideration of the extent to which land markets, especially those for sales and purchase, transfer land across farm size strata, and of ways in which public policy can help to make such an outcome more likely, will be needed.

Rental markets: Results for rental market participation are illustrated in columns 1 and 2 of table 5, with all coefficients reported as marginal probabilities. Agricultural ability is indeed highly significant for those who rent in, but not for those who rent out land. As predicted, land rental has a strong redistributive impact as indicated by the negative sign of the coefficient on land ownership in the rent-in and the positive one in the rent out equation. The fact that households' endowment with agricultural assets and consumer goods increase their propensity to rent in points toward the presence of working capital constraints. Rental markets provide land access to the young and relatively uneducated; higher levels of education reduce the propensity to rent in up to a level of about 7 years of completed schooling after which the propensity to rent in increases again. Large households are more likely to rent in land while female-headed ones are less likely to do so, pointing to labor market imperfections that make it easier to use labor in home production. Finally, the high level of significance and the large size of the coefficient on the share of producers practicing in land rental in the village suggest that the level of rental market activity varies considerably across localities. One interpretation of this is that factors associated with perceived security of tenure, the ease with which information on rental can be obtained and contracts be enforced, continue to constitute an impediment to the unrestricted functioning of rental markets.

The coefficients for renting out are in many ways a mirror image of what had been obtained for renting in. In line with what was found earlier, characteristics of the local economy appear as a key determinant of renting-out decisions; the share of households in the village who have members participating in the offfarm economy is highly positive and significant, as is the level of land rental in the village. In addition, the propensity to rent out increases up to a level of about 4.5 years of education, large owners are more likely to rent out while female headed households are slightly less likely to do so.

Concerning the magnitude of the coefficients obtained, we note that the scope for renting in decreases rapidly with higher land ownership. To illustrate, a household with 2 ha of land will be 14 percentage points less likely than one that does not own land. Similarly, a male headed household with 7 members and a head aged 30 is $8 \%$ more likely to rent in land than one headed by a 50 -year old female with only 2 members. Increasing the share of renters in the village by 10 points is predicted to increase everybody's propensity to rent in by 2 points. Slightly smaller orders of magnitude are found for renting out.

Compared to these relatively large effects, the impact of agricultural ability, while significant, remains minor; noting that the difference between the $10^{\text {th }}$ and the $90^{\text {th }}$ percentile in terms of ability is only about 
3.5 percentage points, one notes that shifting a producer from the lower end to the top of the ability distribution would increase her propensity to rent in by less than 2 percentage points. We interpret this as an indication that, even though land rental markets have started to work in the right direction, even for rental markets ability alone will often not be sufficient to overcome constraints on their participation posed by imperfections in other markets as well as other location-specific impediments (e.g. violence and drug money) to the smooth operation of such markets. Mechanisms that would ensure that ability translates more effectively into demand could therefore be useful.

Sales markets: Results for sales and purchase markets as illustrated in columns 3 and 4 of table 5 lead to two surprising conclusions. First, the negative and significant coefficient on ability for those who sold land suggests that at least some inefficient producers are starting to get rid of some of their land. This is in line with the descriptive evidence which pointed to lack of profitability and the need to repay debts as a key reason for participation in land sales markets and suggests that broader policies are starting to have an impact on observed outcomes in markets. Second, households with lower land endowments were more likely to have acquired land while larger land owners were more likely to have sold land. This suggests that, contrary to what one might have expected in view of continuing concerns about land reconcentration, land sales markets have, in the sample considered here, performed a redistributive role. ${ }^{9}$ In fact, comparing the size of the coefficients on land owned for buying/renting in and selling/renting out, respectively, suggests that it is easier for those without land to acquire land through the rental market whereas those with high land endowments would prefer selling to renting. We also note that, compared to rental, the intergenerational dimension is more pronounced in the land sales markets as the propensity to buy land decreases rapidly with age while the tendency to sell land increases with age, though at a slower rate. At the same time, the impact of education is almost identical in magnitude for buying and renting in, though less significant for renting out.

Turning to the magnitude of the coefficients, one notes that a key factor prompting households to purchase land is their non-agricultural wealth; increasing the value of households' endowment with consumer goods from the $10^{\text {th }}$ to the $90^{\text {th }}$ percentile of the distribution would increase the propensity to buy land by about $6.5 \%$ points. On the other hand, the two most important factors leading households to sell land are the level of initial land ownership and their access to non-farm income. A one ha increase in land ownership increases the propensity to sell by about $3 \%$ points, similar to the increase observed through access to non-farm income. Taking these factors together, one notes that lack of profitability, together with large land sizes, does lead producers to sell off land although it is not a major determinant.

\footnotetext{
${ }^{9}$ This does not mean that in locations not covered by our sample, especially those characterized by high levels of violence and/or continuing inflows of drug money, tendencies toward speculative land accumulation may not persist.
} 
At the same time, capital constraints appear to be more important in sales than in rental markets, thus precluding efficient producers from acquiring land through this channel.

Land reform: To compare the result of the government-sponsored land reform process with those obtained through the operation of markets, we estimate equation (3c) for beneficiaries of land reform. Doing so yields a number of rather surprising findings. First, we find that the coefficient on the original land endowment is positive and highly significant at the $1 \%$ level. This, together with the lack of significance of the coefficients on other agricultural and consumer assets, suggests that the government's land reform efforts failed to target the land poor, something that would be consistent with the hypothesis of a land reform process that is relatively centralized and not well attuned to local conditions and needs.

A second surprising finding relates to the negative coefficient on agricultural ability (significant at the $10 \%$ level) which suggests that land reform beneficiaries are on average less productive than the rest of rural producers. To explore whether this is only a temporary effect, we interacted the farmer's ability with the time when the land was acquired (not reported). The fact that the coefficient of this variable is not significant leads us to conclude that land reform beneficiaries' level of ability failed to improve over time. In addition to these findings, the regression for reform beneficiaries also suggests that households who benefited from land reform are larger than the average, they have slightly lower education (significant at $10 \%$ ) and, despite having been awarded areas that are much larger than those owned by the median farmer, more likely to engage in off-farm activities. This is consistent with the descriptive statistics on relatively low partial productivity per unit land area presented earlier (table 4). In addition to suggesting that the model followed in earlier reforms was in line neither with goals of poverty reduction nor productivity enhancement, this implies that remaining restrictions on the ability of land reform beneficiaries to transfer their land might constitute an important impediment to increased productivity on these lands which would ultimately also translate into higher levels of welfare for their owners.

Comparing these results with those emerging from tobit regressions with the area transferred as the dependent variable (table 6) broadly reinforces the picture painted earlier: In fact, all the variables except the (initial) land endowment and the level of agricultural ability are almost identical in significance and relative magnitude to the ones estimated in the probit. Concerning the latter, it appears that, both for renting in and for purchasing land, access to assets is a critical precondition and that, even though more able and land-poor producers may have a greater propensity to rent in land, wealth constraints may outweigh their productivity advantage and preclude them from purchasing land. Although unproductive large farmers are more likely to sell, the land freed up through such sales is unlikely to be transferred to small producers, thereby limiting the impact such sales will have on the distribution of land ownership. 


\section{Implications for policy}

Survey statistics and evidence on continuing land concentration due to non-market mechanisms especially involuntary displacement, outside the sample areas support the notion that, even though better functioning of land markets is an indispensable first step toward improving access to land by the poor, additional measures will be required to help make a significant impact on the land ownership distribution. Although not sufficient to establish causality, review of transfers of land from large to small producers points toward a number of characteristics that were regularly associated with success and that may therefore constitute important elements in any program that aims to increase poor but productive producers' access to land over and above what is currently accomplished through markets and thus make a contribution to equalize the land ownership distribution. We use this evidence to discuss how some of these elements could be integrated with ongoing efforts to strengthen the role of local governments in overall territorial planning.

\subsection{Land market operation and changes in land concentration}

Descriptive evidence from the survey confirms that the lion's share of land transactions occurs within the same farm size stratum. Concerning changes in the land ownership distribution, the top panel of table 7 provides evidence for segmentation of markets in the sense that the majority of sales by small producers are concluded with other smallholders $(87 \%)$ while $50 \%$ of large farmers sell to large farmers or enterprises, consistent with earlier studies that found that, despite considerable activity in land markets, few sales or purchases had been concluded across farm size strata (FAO 1994). One notes that almost two thirds of land sales (62\%) are undertaken by small producers with a farm size below 15 ha. The main reason prompting those who sold land in the 1994-99 period to do so was to pay debts (47\%) followed by "other", a category that includes violence and local security $(23 \%)$, the need to generate liquidity for purchase of consumer goods (16\%), lack of profitability and the desire to buy land elsewhere (about 7\% each). Lack of profitability and the need to pay debts together are slightly more prevalent among large producers (64\%) compared to medium (57\%) and small ones $(50 \%)$, as is the selling of land for security reasons ( $28 \%$ compared to $14 \%$ for medium and $24 \%$ for small farms). Evidence on land buyers displayed in the bottom panel of table 6 provides additional support to the hypothesis that high transaction costs limit the extent of land sales across farm size groups. One notes that almost all of the land purchased by small farmers (94\%) originated from other smallholders rather than from large farmers. Large buyers obtained the land bought about equally from small and large producers (46\% each). While further evidence would be useful, it appears that there is still considerable scope to improve the functioning of land markets, both by increasing tenure security and by helping to reduce transactions costs especially for transactions across farm size strata. 
Concerning the operational distribution of land, the bottom panel of table 7 illustrates that the biggest share of land rental is accounted for by tenants who own less than 15 ha of land ( $89 \%$ of the total). The mean area rented in by this group is, with 3 hectares, fairly large, although there are some large land owners rent in significant areas bring the average up to 6 ha. One notes that, while large producers rely entirely on cash rent, $44 \%$ of small tenants use sharecropping arrangements, something that would be consistent with the presence of credit constraints or a desire to reduce risk (Otsuka et al. 1992). For households renting out (top panel of table 7), the main reason for supplying land to the rental market seems to be related to age or disability rather than to economic factors, in line with descriptive evidence on the importance of intergenerational transfers. We also note that "other" reasons for renting out are reported by less than $10 \%$ of sample households. The size of area rented out, 1.6 ha overall (but only 0.2 ha in the group of small producers with a land endowment between 0 and $15 \mathrm{ha}$ ) is surprisingly small compared to what is reported for renting in. One possible explanation for this, as well as the low share of producers who report that economic incentives prompt them to rent out land, can be that those who rented out all of their land will, by design, not appear in the sample.

A second issue of concern is that, in addition to the limited impact of markets in redistributing land due to intra-stratum sales, the outcomes obtained through markets may be more than outweighed by changes in land ownership and access that are not mediated by markets, largely in the context of involuntary displacement of small producers. ${ }^{10}$ As these phenomena tend to occur in areas that are geographically distinct from those where markets operate, traditional surveys may not be a good source of information on either the extent or the magnitude of this phenomenon. New evidence, however, illustrates not only the large size of this problem but also its close link to land issues. A key reason for the latter is the fact that, because territorial control is a key element in the war strategies of guerrillas and paramilitary forces, expulsion of land users becomes a tactical element in the armed struggle, with far-reaching consequences for household welfare and livelihood opportunities.

This is supported by the fact that, in a large survey that covered most of the country's territory, more than $60 \%$ of IDPs indicated that they used land before being displaced, a share that is much larger than the percentage of land owners in the overall population (World Bank 2003a) and econometric evidence for a smaller sample (Kirchhoff and Ibanez 2001). In fact, displacement may be driving what is often described as an agrarian counter-reform of massive proportions. Estimates put the aggregate amount of land abandoned by internally displaced people in recent years at 4 million hectares (Global IDP Project 2003), almost three times more than has been redistributed at high cost during more than three decades of land reform. In addition to the impact on the level of land concentration, such massive displacement will also

\footnotetext{
${ }^{10}$ This can happen because it is very difficult, if not impossible, to conduct surveys in areas that have recently been affected by displacement.
} 
affect the productivity of land use and the welfare of those concerned. Productivity will suffer because the land abandoned by IDPs is unlikely to be effectively utilized by their successors. Because their agricultural skills are normally of little use in the urban or peri-urban areas to which they are driven, the welfare of those displaced who previously made their living from agriculture is likely to be more severely affected than that of other groups who suffer from displacement.

\subsection{Characteristics of successful land transactions transcending farm size barriers}

The two key results from our analysis, namely that markets make a modest, though limited, contribution to improving land access by the productive poor but that land accumulation, especially in the context of involuntary displacement, can easily outweigh the results of market forces, imply a two-fold challenge for policy. On the one hand, it will be necessary to create an environment where productivity-related factors and market forces rather than speculation, violence, and power, will affect outcomes. On the other hand, there may be scope for addressing some of the constraints and shortcomings that have made it difficult for markets to provide greater land access in a way that does not, as was the case with many "old style" land reforms, try to substitute for markets but rather complement them in areas where they might otherwise fail. $^{11}$

To illustrate this, we review characteristics that were systematically associated with success ${ }^{12}$, measured either as an increase in the productivity of the farm or of beneficiaries' income compared to the pretransfer situation, or by the fact that after the transfer beneficiary households are able to obtain an absolute income of at least two minimum salaries of a random sample of beneficiaries in 32 projects that had transferred land from large to small producers (Suarez and Vinha 2003). Table 8 presents results for the total sample and each of the subgroups mentioned. Of the 111 households interviewed, 59 (53\%) increased productivity compared to the pre-transfer situation and $64(57 \%)$ were associated with an increase in beneficiaries' income. At the same time, only 32 households (24\%) obtained an income of more than two minimum salaries-still short of the goal of three minimum salaries enunciated in the land reform legislation, which was achieved by only $13 \%$ of those in the sample.

Project characteristics: Compared to those that are based on private sector participation and initiative, projects sponsored by the government land reform agency were significantly less likely to have been successful. As the first line of Table 8 illustrates, only $28 \%$ of the projects that achieved an increase in

\footnotetext{
${ }^{11}$ Due largely to shortcomings in implementation, even the land reforms conducted in Colombia under Law 160 had, in practice, more similarities with "old style" top down land reforms rather than a more decentralized approach that builds on initiative by beneficiaries and empowers them rather than bureaucrats (Rojas 2001).

${ }^{12}$ The definition of a project as "successful" implies that a given project (a) transfers to small and medium-sized producers property rights for large properties that are appropriate for agricultural use but are not or not fully utilized; (b) allows new users to make more productive use of the land, thereby increasing the intensity of land use; (c) improves their standard of living; (d) does so in a way that the costs and benefits of the transfer (including complementary investments) allows for a program that is fiscally sustainable and can be scaled up in response to need; and (e)
} 
productivity and $22 \%$ of those that achieved more than two minimum salaries were INCORA projects, compared to $50 \%$ and $46 \%$, respectively, of those that did not. The exact opposite is true for market-based transfers, which make up $72 \%$ of those where beneficiaries receive more than two minimum salaries and $58 \%$ of those with a productivity increase. One of the reasons for the limited success of INCORA projects appears to be that, in quite a number of cases, the institution was forced to undertake certain transactions due to political pressure or violence. Transactions motivated by violence were significantly less successful in increasing income (comprising only $18 \%$ of those that managed to improve income compared to $23 \%$ of those that did not), pointing toward the importance of the broader economic and market environment to facilitate success of interventions to reduce land concentration. A third variable that distinguishes successful from unsuccessful projects is beneficiary participation. In a much higher share of projects where productivity or income increased or where an income above two minimum salaries was achieved, beneficiaries participated in selecting the organization of production and, (in the latter case) the purchase price of the farm.

Access to capital and other markets: A second set of factors that seems critical for success is the ability to access capital as well as output markets, in line with anecdotal evidence suggesting that the success of many land reform projects who, being focused only on transfer of land, have been caught in a liquidity trap with few opportunities for economic advancement. Lack of access to any working capital is a key determinant of failure in all dimensions whereas projects that had access to working capital of different sizes and to bank credit were significantly more successful than those who had not. The importance of liquidity on the input side is matched by the relevance of access to market information and transport on the output side.

Household attributes: Although higher levels of education are significantly associated with the ability to increase income above a minimum level, they are less relevant for the ability to increase either income or productivity. To the contrary, whether or not beneficiaries live on the farm appears to be a key condition for increased income as well as productivity.

\subsection{Implications for programs to overcome land concentration}

The above discussion illustrates that, to facilitate land transfers from large to small farmers, it will be critical to provide economic incentives that would increase the cost of holding land speculatively and, for households threatened by involuntary displacement, increase tenure security. ${ }^{13}$ If the policy environment is adequate, sales and rental markets can help transfer land to poor and productive producers but, in order

do not reduce the overall mobility of land. Also note that the measure of income used here, i.e. 2 minimum salaries, is still short of the goal of three minimum salaries enunciated in current land reform legislation. 
to make an impact on the land ownership distribution, additional support to economically viable projects that aim to bring highly underutilized land into more intensive production may be needed and could yield significant benefits ${ }^{14}$. Successful projects to accomplish this were associated with active participation and interest by beneficiaries and access to capital and output markets. A concerted effort, building on initiatives at the national and local levels seems to have considerable potential in this respect.

At the local level, it will be necessary to establish a policy framework (including land taxation) that encourages operation of land (rental and sales) markets based on private sector initiative and, if additional support is to be provided, to systematically identify land use potential, compare it to present utilization, and identify complementary infrastructure and other investments that may help to bring underutilized land into productive use. Rather than intervening in an ad hoc manner that might upset local processes, national institutions should focus on providing incentive-compatible policy guidelines, monitoring land market trends across localities and, where needed, technical and financial support in a way that would build on the existing infrastructure at the local and departmental levels. Even though many of them have a strong environmental or urban bias, land use plans (planes de ordenamiento territorial or POT) which have to be put together by all local governments provide a basis on which further efforts in this regard can be built (Zapata and Arismendy).

\section{Conclusion and policy implications}

This paper compares the performance of decentralized land markets that are based on private initiative to that of land reform that is sponsored by the central government. We find that, quite surprisingly, land markets make a significant contribution to greater equalization of the operational structure of land holdings and, to a more limited extent, the ownership structure. The rather disappointing performance of land reforms suggests that one can not take it for granted that government reforms will be more effective in addressing this issue. This implies that significant advances for more efficient land utilization and greater access to land by the poor can be made by strengthening the framework to ensure that titles are secure, information is freely available, there is access to financial instruments, and long-term contracts can be entered into.

At the same time, our results show that markets alone are unlikely to be able to deal with the deep-rooted problems of unequal land access and the associated inefficient utilization of this factor of production in Colombia. The main reasons are threefold, namely (i) for markets to function, minimum levels of physical

\footnotetext{
${ }^{13}$ Being characterized by significant pressure for speculative land accumulation and concentration, a limited productive infrastructure, and the threat of involuntary displacement, locations where the government has implemented land reform in the past may be the most difficult for land reform

${ }^{14}$ Surprisingly, case study interviews suggest that even large landlords understand that, in order to preserve social peace and reduce the scope for violence, negotiated solutions that provide greater land access for the productive poor will be needed. Apparently they would also be willing to
} 
security and rule of the law are required; (ii) economic incentives such as a realistic level of land taxation to bring land to its most productive use instead of engaging in speculative land accumulation need to be in place; and (iii) even where the above conditions hold, financing constraints are likely to limit the ability of the poorest groups in society to take advantage of the opportunities offered.

Instead of trying to substitute for well-functioning markets, government policy should thus aim to create the conditions in which markets can operate to the best of their capacity and, once this has been achieved, to provide specific assistance to help the poor overcome the shortcomings and finance constraints impeding their ability to access land even with well-functioning markets. Re-orienting land reform policy along these lines would constitute a departure from the centralized model followed thus far. Instead it would provide assistance to complement efforts by local governments who have already demonstrated their concern about broad land access and effective land use to ensure that such efforts will not only improve productivity but do so in a way that provides maximum benefits to the poor.

make some contributions (including provision of land) to such a process as long as they have a possibility of affecting the selection of beneficiaries and, jointly with these, managing the production process (Suarez and Vinha 2003). 
Table 1. Structure of Landownership and Use in Colombia, 1984 and 1997

\begin{tabular}{llccc}
\hline & \multicolumn{3}{c}{ By Productive Capacity } & Units \\
& $\mathbf{1 9 8 4}$ & Area & $\mathbf{1 9 9 7}$ & $\mathbf{1 9 9 7}$ \\
\cline { 2 - 5 } Small (0-2 UAF) & 23.15 & 21.40 & 89.92 & 91.11 \\
Medium (2-10 UAF) & 30.50 & 24.80 & 8.68 & 7.81 \\
Large (> 10 UAF) & 46.35 & 53.80 & 1.40 & 1.08 \\
\hline & & & By Extension & Units \\
& & Area & $\mathbf{1 9 8 4}$ & $\mathbf{1 9 9 7}$ \\
\hline 100 hectares & $\mathbf{1 9 8 4}$ & $\mathbf{1 9 9 7}$ & 96.90 & 97.40 \\
$100-500$ hectares & 40.00 & 34.50 & 2.70 & 2.30 \\
$>500$ hectares & 27.50 & 20.50 & 0.40 & 0.30 \\
\hline
\end{tabular}

Sources: Top panel from Machado (1999); bottom panel from Mondragon (1999).

Table 2. Actual and Potential Land Use in Colombia, 1985 and 1999

\begin{tabular}{|c|c|c|c|c|c|c|c|c|}
\hline & \multicolumn{2}{|c|}{ Potential (1985) } & \multicolumn{3}{|c|}{ Actual Use (1987) } & \multicolumn{3}{|c|}{ Actual Use (1999) } \\
\hline & $\begin{array}{c}\text { Million } \\
\text { Hectares } \\
\end{array}$ & $\%$ & $\begin{array}{c}\text { Million } \\
\text { Hectares }\end{array}$ & $\%$ & $\begin{array}{c}\text { Of } \\
\text { Potential }\end{array}$ & $\begin{array}{c}\text { Million } \\
\text { Hectares }\end{array}$ & $\%$ & $\begin{array}{c}\text { Of } \\
\text { Potential }\end{array}$ \\
\hline Agri. crops (annual or perm.) & 14.0 & 12.6 & 5.3 & 4.64 & 36.8 & 4.4 & 3.9 & 30.6 \\
\hline Pasture & 19.2 & 16.8 & 40.1 & 35.1 & 209 & 41.2 & 36 & 215 \\
\hline Forest & 78.3 & 68.6 & 58.9 & 51.6 & 75.2 & 65.4 & 57 & 83.5 \\
\hline Nonagricultural \& urban & & & 8.5 & 7.44 & & & & \\
\hline Urban and water & 2.3 & 2.01 & 1.4 & 1.23 & 60.9 & 3.2 & 2.8 & 139 \\
\hline Total & 114.2 & 100 & 114.2 & 100 & & 114.2 & 100 & \\
\hline
\end{tabular}

Source: Anuario Estadístico del Ministerio de Agricultura, 1999.

Table 3: Public spending for land reform and related projects, Colombia different years (Bn. 2000 Pesos)

\begin{tabular}{|c|c|c|c|c|c|c|}
\hline & 1985 & 1995 & 1996 & 1997 & 1998 & 1999 \\
\hline Total INCORA & 3.12 & 88.24 & 130.78 & 124.26 & 89.34 & 69.00 \\
\hline of which technical assistance & $19.4 \%$ & $11.4 \%$ & $3.0 \%$ & $3.5 \%$ & $9.7 \%$ & $18.6 \%$ \\
\hline of which grants & $0.0 \%$ & $5.7 \%$ & $52.1 \%$ & $55.2 \%$ & $60.3 \%$ & $20.1 \%$ \\
\hline of which infrastructure & $41.6 \%$ & $12.3 \%$ & $4.7 \%$ & $16.6 \%$ & $1.6 \%$ & $1.1 \%$ \\
\hline of which titling and cadastre (RA) & $29.9 \%$ & $56.4 \%$ & $31.1 \%$ & $16.2 \%$ & $16.5 \%$ & $25.7 \%$ \\
\hline Caja Agraria (credit \& vivienda) & 4.95 & 32.10 & 237.27 & 197.29 & 81.59 & 132.61 \\
\hline INCORA + Caja Agraria & 8.07 & 120.34 & 368.04 & 321.55 & 170.93 & 201.62 \\
\hline Total Central Spending & 40.28 & 707.12 & 1039.15 & 931.23 & 891.42 & 791.32 \\
\hline Spending by municipalities & 0.00 & 435.12 & 593.29 & 764.69 & 967.61 & 1253.71 \\
\hline Total Min. of Agriculture & 40.28 & 1142.24 & 1632.44 & 1695.91 & 1859.03 & 2045.03 \\
\hline INCORA of central & $7.8 \%$ & $12.5 \%$ & $12.6 \%$ & $13.3 \%$ & $10.0 \%$ & $8.7 \%$ \\
\hline INCORA of total & $7.8 \%$ & $7.7 \%$ & $8.0 \%$ & $7.3 \%$ & $4.8 \%$ & $3.4 \%$ \\
\hline INCORA + Caja of central & $20.0 \%$ & $17.0 \%$ & $35.4 \%$ & $34.5 \%$ & $19.2 \%$ & $25.5 \%$ \\
\hline INCORA + Caja of total & $20.0 \%$ & $10.5 \%$ & $22.5 \%$ & $19.0 \%$ & $9.2 \%$ & $9.9 \%$ \\
\hline
\end{tabular}

Source: Food and Agricultural Organization (2000). 
Table 4: Descriptive statistics for total and household samples

\begin{tabular}{|c|c|c|c|c|c|c|c|}
\hline & \multicolumn{7}{|c|}{ Total sample } \\
\hline & Total & Not renting & Renting in & Renting out & Selling & Buying & Reform benef. \\
\hline No. of enterprises & 1275 & $81.96 \%$ & $13.96 \%$ & $4.24 \%$ & $5.80 \%$ & $10.59 \%$ & $8.55 \%$ \\
\hline Land cultivated 1999 (mean) & 29.12 & 31.21 & 8.62 & 55.97 & 56.62 & 24.66 & 15.09 \\
\hline Land cultivated 1999 (median) & 3.91 & 4.14 & 2.59 & 7.00 & 5.85 & 4.75 & 8.37 \\
\hline Land owned 1997 (median) & 3.15 & 4.01 & 0.00 & 8.97 & 5.03 & 3.76 & 9.70 \\
\hline Land owned 1999 (median) & 3.15 & 4.10 & 0.00 & 6.70 & 5.10 & 4.51 & 7.95 \\
\hline Mean livestock assets (US \$) & 6984 & 7797 & 1468 & 9228 & 12132 & 8216 & 4018 \\
\hline Mean machinery assets (US \$) & 849 & 848 & 471 & 2095 & 3003 & 898 & 297 \\
\hline Total value of output 99 (median) & 1212.41 & 1212.98 & 1089.41 & 2252.70 & 1572.21 & 1733.71 & 1200.46 \\
\hline \multirow[t]{3}{*}{ Value of output per ha 99 (median) } & 326.70 & 295.64 & 509.72 & 290.84 & 281.89 & 359.47 & 166.92 \\
\hline & \multicolumn{7}{|c|}{ Household sample } \\
\hline & Total & Not renting & Renting in & Renting out & Selling & Buying & Reform benef. \\
\hline No. of households & 1011 & $83.68 \%$ & $12.66 \%$ & $3.86 \%$ & $6.33 \%$ & $10.19 \%$ & $10.09 \%$ \\
\hline Household size & 4.62 & 4.56 & 4.95 & 4.82 & 4.78 & 4.55 & 5.51 \\
\hline Head's age & 53.39 & 53.94 & 49.48 & 53.97 & 56.73 & 44.46 & 51.93 \\
\hline Head's education & 5.67 & 5.67 & 5.49 & 6.26 & 6.48 & 6.17 & 5.35 \\
\hline Female headed & $18.20 \%$ & $18.91 \%$ & $10.16 \%$ & $28.21 \%$ & $14.06 \%$ & $8.74 \%$ & $15.69 \%$ \\
\hline No of persons $<=14$ years & 1.38 & 1.33 & 1.72 & 1.51 & 1.08 & 1.49 & 1.94 \\
\hline No of persons $14-55$ years & 2.45 & 2.41 & 2.66 & 2.69 & 2.69 & 2.55 & 2.87 \\
\hline No of persons $>55$ years & 0.79 & 0.83 & 0.57 & 0.62 & 1.02 & 0.51 & 0.70 \\
\hline Mean level of education & 6.55 & 6.54 & 6.49 & 6.86 & 7.15 & 6.76 & 6.42 \\
\hline Land cultivated 1999 (mean) & 14.47 & 15.84 & 5.68 & 13.77 & 23.43 & 11.24 & 13.89 \\
\hline Land cultivated 1999 (median) & 3.63 & 3.77 & 2.87 & 5.20 & 4.81 & 4.92 & 8.28 \\
\hline Land owned 1997 & 2.75 & 3.48 & 0.01 & 8.29 & 4.29 & 4.12 & 9.76 \\
\hline Land owned 1997 (median) & 2.75 & 3.48 & 0.01 & 8.29 & 4.29 & 4.12 & 9.76 \\
\hline Mean livestock assets (US \$) & 4021 & 4530 & 1112 & 2428 & 4553 & 3924 & 4045 \\
\hline Mean machinery assets (US \$) & 509 & 500 & 619 & 343 & 1064 & 275 & 266 \\
\hline Total value of output 99 (median) & 1168.79 & 1161.73 & 1166.00 & 1849.46 & 1151.54 & 1742.77 & 1210.99 \\
\hline Value of output per ha 99 (median) & 337.39 & 310.86 & 452.79 & 370.34 & 291.38 & 369.47 & 165.47 \\
\hline
\end{tabular}

Source: Own computation from the PECVE and SECVE. 
Table 5: Probit regression for participation in land sales and rental markets or receipt of land through land reform

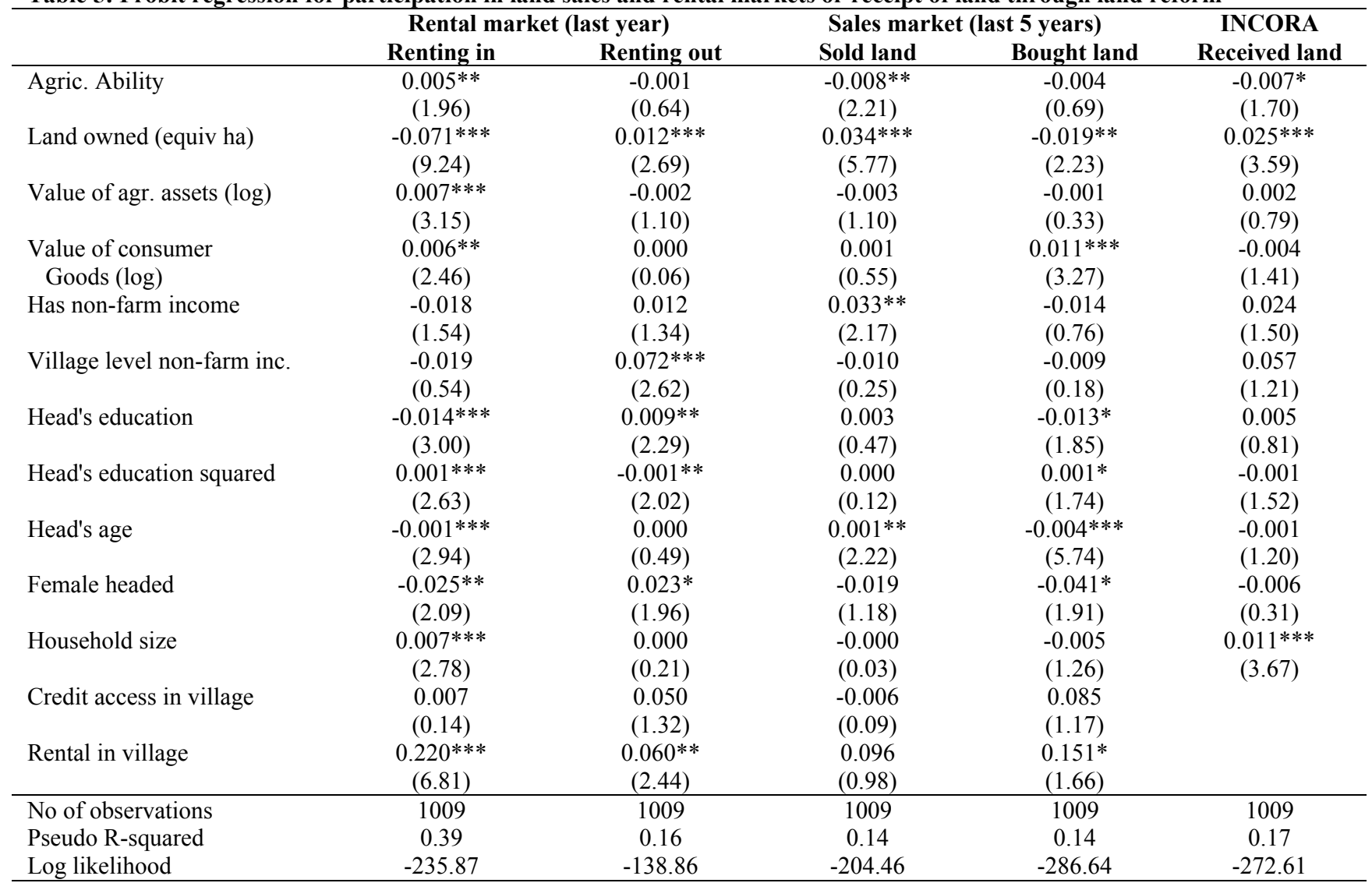

Absolute value of $\mathrm{z}$-statistics in parentheses

* significant at $10 \%$; ** significant at $5 \% ; * * *$ significant at $1 \%$

Regional dummies included but not reported separately.

${ }^{1}$ The variable for land owned and assets refer to 1999 for renters, and to 1994 for the rest. 
Table 6: Tobit regression for area transferred in land sales and rental markets

\begin{tabular}{|c|c|c|c|c|}
\hline & \multicolumn{2}{|c|}{ Rental markets (last year) } & \multicolumn{2}{|c|}{ Sales markets (last 5 years) } \\
\hline & Area rented in & Area rented out & Area sold & Area bought \\
\hline \multirow[t]{2}{*}{ Land owned (equiv ha) } & $-12.250 * * *$ & $15.855^{* * *}$ & $27.439 * * *$ & -1.467 \\
\hline & $(7.71)$ & $(2.67)$ & $(5.27)$ & $(0.62)$ \\
\hline \multirow[t]{2}{*}{ Agric. ability } & -0.173 & -6.498 & $-16.672 * *$ & -1.800 \\
\hline & $(0.12)$ & $(1.16)$ & $(2.57)$ & $(0.64)$ \\
\hline \multirow[t]{2}{*}{ Agricultural assets $(\log )$} & $1.693 * * *$ & -3.698 & $-5.053 * *$ & -0.173 \\
\hline & $(3.68)$ & $(1.55)$ & $(2.08)$ & $(0.19)$ \\
\hline \multirow[t]{2}{*}{ Consumer goods (log) } & $0.952 * *$ & -0.611 & -1.787 & $2.932 * * *$ \\
\hline & $(2.12)$ & $(0.28)$ & $(0.77)$ & (3.11) \\
\hline \multirow[t]{2}{*}{ Has non-farm income } & -2.001 & 13.377 & $34.510 * *$ & -0.597 \\
\hline & $(0.83)$ & $(1.10)$ & $(2.46)$ & $(0.11)$ \\
\hline \multirow[t]{2}{*}{ Village level non-farm inc. } & 1.189 & $86.938^{* *}$ & 5.476 & -9.082 \\
\hline & $(0.18)$ & $(2.40)$ & $(0.15)$ & $(0.61)$ \\
\hline \multirow[t]{2}{*}{ Head's Education } & $-2.657 * * *$ & $10.727 *$ & 5.522 & $-4.606^{* *}$ \\
\hline & $(2.77)$ & $(1.89)$ & $(0.96)$ & $(2.23)$ \\
\hline \multirow[t]{2}{*}{ Head's education squared } & $0.178 * * *$ & -0.556 & -0.053 & $0.292 * *$ \\
\hline & $(2.81)$ & $(1.50)$ & $(0.15)$ & $(2.18)$ \\
\hline \multirow[t]{2}{*}{ Head's age } & $-0.215^{* *}$ & 0.265 & $1.028 * *$ & $-1.149 * * *$ \\
\hline & $(2.54)$ & $(0.66)$ & $(2.21)$ & $(5.62)$ \\
\hline \multirow[t]{2}{*}{ Female headed } & $-8.956^{* *}$ & $21.258^{*}$ & -22.856 & -8.994 \\
\hline & $(2.54)$ & $(1.68)$ & $(1.24)$ & $(1.23)$ \\
\hline \multirow[t]{2}{*}{ Household size } & $0.848^{*}$ & 1.746 & 0.146 & -1.282 \\
\hline & $(1.78)$ & $(0.76)$ & $(0.06)$ & $(1.15)$ \\
\hline \multirow[t]{2}{*}{ Constant } & -8.712 & $-221.078 * * *$ & $-251.234 * * *$ & 23.082 \\
\hline & $(1.09)$ & $(4.40)$ & $(4.97)$ & $(1.30)$ \\
\hline Observations & 881 & 881 & 881 & 881 \\
\hline Pseudo R-squared & 0.12 & 0.07 & 0.08 & 0.06 \\
\hline Log likelihood & -604.90 & -293.60 & -434.95 & -651.47 \\
\hline
\end{tabular}

Absolute value of t-statistics in parentheses

significant at $10 \% ; * *$ significant at $5 \% ; * * *$ significant at $1 \%$

Absolute value of $\mathrm{z}$-statistics in parentheses

* significant at $10 \% ; * *$ significant at $5 \% ; * * *$ significant at $1 \%$

Regional dummies included but not reported separately.

${ }^{1}$ The variable for land owned and assets refer to 1999 for renters, and to 1994 for the rest. 
Table 7: Details on performance of land rental and sales markets

SALES MARKETS

\begin{tabular}{lcccc}
\hline & \multicolumn{3}{c}{ Land sellers } & \\
Land size class (ha) & Total & $0-15$ & $15-50$ & $>50$ \\
\hline Sold land last 5 years & 74 & $62 \%$ & $19 \%$ & $19 \%$ \\
Area sold (ha) & 3.3 & 0.2 & 1.5 & 29.0 \\
Land sold to(percentages) & & & & \\
Small farmer & 75.7 & 87.0 & 85.7 & 28.6 \\
Big farmer & 8.1 & 2.2 & & 35.7 \\
Enterprise & 5.4 & 2.2 & 7.1 & 14.3 \\
Other \& not reported & 10.8 & 8.7 & 7.1 & 21.4 \\
Reason for selling (percentages) & & & & 42.9 \\
Pay debts & 47.3 & 45.7 & 57.1 & - \\
Buy consumption goods & 16.2 & 17.4 & 28.6 & 21.4 \\
Lack of profitability & 6.8 & 4.3 & - & 7.1 \\
Buying land elsewhere & 6.8 & 8.7 & - & 28.6 \\
Other reasons (incl. security) & 23.0 & 23.9 & 14.3 & $>50$ \\
\hline & & \multicolumn{2}{c}{ Land buyers } & $10 \%$ \\
Land size class (ha) & Total & $0-15$ & $15-50$ & 271.60 \\
Boughtlandlast5years & 135 & $73 \%$ & $18 \%$ & 46.15 \\
Area bought (ha) & 39.30 & 5.78 & 50.38 & 46.15 \\
Land bought from(percentages) & & & & 7.69 \\
Small farmer & 85.19 & 93.88 & 70.83 & 29.17 \\
Big farmer & 12.59 & 4.08 & - & \\
Other \& not reported & 2.22 & 2.04 & & \\
\hline
\end{tabular}

\section{RENTAL MARKETS}

\begin{tabular}{|c|c|c|c|c|}
\hline \multirow[b]{2}{*}{ Land size class (ha) } & \multicolumn{4}{|c|}{ "Landlords" renting out } \\
\hline & Total & $0-15$ & $15-50$ & $>50$ \\
\hline Rented out in 1999 (Obs) & 54 & $69 \%$ & $13 \%$ & $19 \%$ \\
\hline Area rented out & 1.57 & 0.19 & 1.16 & 12.53 \\
\hline \multicolumn{5}{|l|}{ Reason (percentages) } \\
\hline Age & 22.2 & 21.6 & 14.3 & 30.0 \\
\hline Widowhood or disability & 37.0 & 35.1 & 57.1 & 30.0 \\
\hline Better job & 24.1 & 27.0 & 14.3 & 20.0 \\
\hline Lack of credit & 7.4 & 8.1 & 14.3 & - \\
\hline \multirow[t]{2}{*}{ Other } & 9.3 & 8.1 & - & 20.0 \\
\hline & \multicolumn{4}{|c|}{ Tenants renting in } \\
\hline Land size class (ha) & Total & $0-15$ & $15-50$ & $>50$ \\
\hline Renting in 1999 (obs) & 178 & $89 \%$ & $8 \%$ & $2 \%$ \\
\hline Area rented in (ha) & 6.03 & 2.99 & 30.23 & 36.13 \\
\hline \multicolumn{5}{|l|}{ Composition of rent paid } \\
\hline Sharecropping (non-cash) & $37.97 \%$ & $43.87 \%$ & - & - \\
\hline Cash & $62.03 \%$ & $56.13 \%$ & $100.00 \%$ & $100.00 \%$ \\
\hline
\end{tabular}

Source: Own computation from the PECVE and SECVE. 
Table 8: Project- and household level factors contributing to land reform project performance

\begin{tabular}{|c|c|c|c|c|c|c|c|c|c|c|}
\hline \multirow{3}{*}{ Project Characteristics } & \multirow{3}{*}{$\begin{array}{c}\text { Total } \\
\text { Sample }\end{array}$} & \multicolumn{3}{|c|}{ Productivity Change } & \multicolumn{2}{|c|}{ Income Change } & \multicolumn{4}{|c|}{ Absolute Income } \\
\hline & & No Incr. & \multicolumn{2}{|l|}{ Increase } & \multirow[t]{2}{*}{ No Incr. } & \multirow[t]{2}{*}{ Increase } & \multirow{2}{*}{\multicolumn{2}{|c|}{$<=2$ msal }} & \multicolumn{2}{|l|}{$>2$ msal } \\
\hline & & & & & & & & & & \\
\hline INCORA & 42.96 & 50 & 28.81 & $* *$ & 48.93 & 31.25 & $* *$ & 45.57 & 21.88 & $* * *$ \\
\hline Market transfer & 38.52 & 30.77 & 57.63 & $* * *$ & 34.04 & 53.13 & $* *$ & 34.18 & 71.86 & $* * *$ \\
\hline Violence was an issue & 25.19 & 23.08 & 18.64 & & 36.17 & 9.38 & $* * *$ & 18.99 & 25 & \\
\hline Beneficiaries selected organ. form & 24.44 & 17.65 & 49.15 & $* * *$ & 19.57 & 45.31 & $* * *$ & 27.85 & 51.61 & $* * *$ \\
\hline Negotiation on price of farm & 25.19 & 21.15 & 22.03 & & 21.28 & 21.88 & & 12.66 & 43.75 & $* * *$ \\
\hline Changes in use of technology & 21.48 & 23.08 & 33.9 & & 27.66 & 29.69 & & 21.82 & 46.88 & $* * *$ \\
\hline \multicolumn{11}{|l|}{ Capital Market Access } \\
\hline Working capital zero & 46.67 & 61.54 & 30.51 & $* * *$ & 57.45 & 35.94 & $* *$ & 51.9 & 28.13 & $* *$ \\
\hline Working capital $>0$ but $<3 \mathrm{mn} \mathrm{P}$ & 28.15 & 17.31 & 45.76 & $* * *$ & 21.28 & 40.63 & $* *$ & 32.91 & 31.25 & \\
\hline Working capital more than $3 \mathrm{mn} \mathrm{P}$ & 25.19 & 21.15 & 23.73 & & 21.28 & 23.44 & & 15.19 & 40.63 & $* * *$ \\
\hline UPA has access to bank credit & 38.52 & 38.46 & 54.24 & $* *$ & 31.91 & 57.81 & $* * *$ & 40.51 & 62.5 & $* *$ \\
\hline Distance to market & 56.69 & 54.21 & 48.4 & & 64.13 & 41.46 & $* * *$ & 52.3 & 48.19 & \\
\hline UPA has access to transport & 54.81 & 59.62 & 81.36 & $* * *$ & 61.7 & 78.13 & $* *$ & 65.82 & 84.38 & $* *$ \\
\hline UPA access to technical assistance & 55.56 & 65.38 & 79.66 & $* *$ & 65.96 & 48.13 & $*$ & 70.89 & 78.13 & \\
\hline UPA access to market information & 42.22 & 50 & 59.32 & & 42.55 & 64.06 & $* *$ & 45.57 & 78.13 & $* * *$ \\
\hline \multicolumn{11}{|l|}{ Household Characteristics } \\
\hline Head has primary education & 35.56 & 38.46 & 47.46 & & 40.43 & 45.31 & & 51.9 & 21.88 & $* * *$ \\
\hline Head has secondary education & 28.15 & 30.77 & 38.9 & & 27.65 & 40.63 & $*$ & 27.84 & 53.13 & $* * *$ \\
\hline Head has professional education & 13.33 & 21.16 & 11.86 & $*$ & 16.15 & 14.06 & & 12.66 & 25 & $* *$ \\
\hline Beneficiary displaced household & 15.56 & 21.15 & 8.47 & $* *$ & 34.04 & 0 & $* * *$ & 17.72 & 6.25 & $*$ \\
\hline Household lives on farm & 51.11 & 42.31 & 67.79 & $* * *$ & 34.04 & 71.88 & $* * *$ & 55.7 & 56.25 & \\
\hline No. of observations & 111 & 52 & 59 & & 47 & 64 & & 79 & 32 & \\
\hline
\end{tabular}


References

Aghion, P., E. Caroli and C. Garcia-Penalosa. 1999. "Inequality and Economic Growth: The Perspective of the New Growth Theories." Journal of Economic Literature 37 (4): 1615-60.

Bardhan, P. 2000. "Wealth Inequality, Wealth Constraints and Economic Performance." 541-603 Atkinson, Anthony B. and Bourguignon, Francois .

Battese, G. E. 1997. "A Note on the Estimation of Cobb-Douglas Production Functions When Some Explanatory Variables Have Zero Values." Journal of Agricultural Economics 48 (2): 250-2.

Benjamin, D. 1995. "Can Unobserved Land Quality Explain the Inverse Productivity Relationship?" Journal of Development Economics 46 (1): 51-84.

Binswanger, H. P., K. Deininger and G. Feder. 1995. "Power, Distortions, Revolt and Reform in Agricultural Land Relations." Handbook of development economics.Volume 3B (1995): 2659-2772 2659-772.

Carter, M. R. 1984. "Identification of the inverse relationship between farm size and productivity: an empirical analysis of peasant agricultural production." Oxford Economic Papers 36 131-45.

Carter, M. R. and D. Mesbah. 1993. "Can Land Market Reform Mitigate the Exclusionary Aspects of Rapid Agro-export Growth?" World Development 21 (7): 1085-100.

Carter, M. R. and F. J. Zimmerman. 2000. "The Dynamic Cost and Persistence of Asset Inequality in an Agrarian Economy." Journal of Development Economics 63 (2): 265-302.

Currie, L. B. 1950. "The Basis of a Development Program for Colombia." Report of a mission headed by L. Currie and sponsored by the International Bank for Reconstruction and Development in collaboration with the Government of Colombia. Washington, D.C.

Conning, J. 2002. "Latifundia Economics." Hunter College Department of Economics WP 02/1. New York.

de Janvry, A., G. Gordillo, J. P. Platteau and E. Sadoulet. 2001. Access to Land, Rural Poverty, and Public Action. Oxford: Oxford University Press.

Deaton, A. 1991. "Saving and Liquidity Constraints." Econometrica 59 (5): 1221-48.

Deininger, K. and P. Olinto. 2000. "Asset Distribution, Inequality and Growth." World Bank Policy Research Working Paper 2375 .

Deininger, K. 1999. "Making Negotiated Land Reform Work: Initial Experience from Colombia, Brazil and South Africa." World Development 27 (4): 651-72.

Deininger, K. 2003. Land policies for growth and poverty reduction World Bank Policy Research Report series. Washington, D.C.: World Bank; Oxford and New York: Oxford University Press.

Deininger, K. and S. Jin. 2002. "Land Rental Markets as an Alternative to Government Reallocation? Equity and Efficiency Considerations in the Chinese Land Tenure System." World Bank Policy Research Working Paper 2930. Washington, DC:

Deininger, K., S. Jin, B. Adenew, S. Gebre-Selassie, and M. Demeke. 2003. "Market and Non-Market Transfers of Land in Ethiopia: Implications for Efficiency, Equity, and Non-Farm Development." World Bank Policy Research Paper 2992. Washington DC: World Bank.

Deininger, K. and P. Mpuga. 2002. "Land Markets in Uganda: Incidence, Impact, and Evolution over Time." World Bank Discussion Paper. Washington DC: World Bank.

FAO. 1994. Mercados de tierras en Colombia. Rome:

FAO. 2000. Colombia, Matrices de Gasto Publico en el Sector Agricola y Rural (1985 y 1995-99). Rome:

Global IDP Project. 5-14-2003. "Profile of Internal Displacement: Colombia." . Geneva: Norwegian Refugee Council.

Grusczynski, D. and C. F. Jaramillo. 2002. "Country Case Study Columbia." World Bank Regional Land Workshop in Pachula, Mexico.

Heath, J. and H. Binswanger. 1996. "Natural Resource Degradation Effects of Poverty and Population Growth Are Largely Policy-Induced: The Case of Colombia." Environment and Development Economics 1 (1): 65-84.

Jaramillo, C. F. 1998. "El Mercado Rural de Tierras en América Latina: Hacia una Nueva Estrategia B." Banco Interamericano de Desarollo, Informe Téchnico No.ENV-124, Washington, DC, 1998. 
Jaramillo, C. F. 2001. "Liberalization, Crisis, and Change: Colombian Agriculture in the 1990s." Economic Development and Cultural Change 49 (4): 821-46.

Kawagoe, T. 1999. "Agricultural Land Reform in Postwar Japan: Experiences and Issues." World Bank Working Paper \#2111.

Kirchhoff, S. and A. M. Ibanez. 2001. "Displacement due to Violence in Colombia: Determinants and Consequences at the Household Level." ZEF-Discussion Papers on Development Policy No. 41 41. Bonn: Center for Development Research.

Machado, A. 1999. "Una Visión Renovada sobre la Reforma Agraria en Colombia." In A.Machado and R.Suarez, eds., El Mercado de Tierras en Colombia. Bogota, DF: TM Editores.

Mondragon, H. 1999. "Ante el Fracaso del Mercado Subsidiado de Tierras." In A.Machado and R.Suarez, eds., El Mercado de Tierras en Colombia. Bogota, DF: TM Editores.

Moyo, S., B. Rutherford and D. Amanor-Wilks. 2000. "Land Reform and Changing Social Relations for Farm Workers in Zimbabwe." Review of African Political Economy 27 (84): 181-202.

Nugent, J. B. and J. A. Robinson. 2002. "Are Endowments Fate?" CEPR Working Paper 3206. London.

Otsuka, K., H. Chuma and Y. Hayami. 1992. "Land and Labor Contracts in Agrarian Economies: Theories and Facts." Journal of Economic Literature 30 (4): 1965-2018.

Putzel, J. 1992. A captive land: The politics of agrarian reform in the Philippines. Manila: Ateneo de Manila University Press.

Rawal, V. 2001. "Agrarian Reform and Land Markets: A Study of Land Transactions in Two Villages of West Bengal, 19771995." Economic Development and Cultural Change 49 (3): 611-29.

Rojas, M. E. 2001. "Evaluacion de las Leyes 30/88 y 160/94 y Diseno de Indicadores para la Medicion de la Reforma Agraria en Colombia." Bogotá, Colombia.

Rosenzweig, M. R. and K. I. Wolpin. 1993. "Credit Market Constraints, Consumption Smoothing, and the Accumulation of Durable Production Assets in Low-Income Countries: Investment in Bullocks in India." Journal of Political Economy 101 (2): 223-44.

Rozelle, S. and J. F. M. Swinnen. 2003. "Transition and Agriculture ." Journal of Economic Literature forthcoming.

Sadoulet, E., R. Murgai and A. de Janvry. 2001. "Access to Land via Land Rental Markets." In de Janvry, A., G. Gordillo, J.-P. Platteau and E. Sadoulet, eds., Access to Land Rural Poverty and Public Action. Oxford: Oxford University Press .

Suarez, R. and K. Vinha. 2003. "Elementos para una Reforma Agraria Efectiva." Informe final. Bogota, Colombia:

Tejo, P. 2003. Mercados de tierras agricolas en America Latina y el Caribe: Una realidad incompleta. Santiago, Chile: CEPAL.

World Bank. 2003a. Land Policies for Growth and Poverty Reduction. Washington, DC: World Bank and Oxford University Press.

World Bank. 2003b. "Rural poverty alleviation in Brazil: Toward an integrated strategy." A World Bank Country Study. Washington DC: World Bank.

Zapata, J. G., and C. Arismendy. 2003. "Ordenamineto Territorial y Reforma Agraria en Colombia: Un nuevo Enfoque Para un Viejo Problema. " Mimeo. Bogotá.

Zeldes, S. P. 1989. "Consumption and Liquidity Constraints: An Empirical Investigation." Journal of Political Economy 97 (2): 305-46.

Zimmerman, F. J. and M. R. Carter. 2003. "Asset Smoothing, Consumption Smoothing and the Reproduction of Inequality under Risk and Subsistence Constraints." Journal of Development Economics 71 (2): 233-60. 